\title{
HERBALISTS AND MEDICAL BOTANISTS IN MID-NINETEENTH-CENTURY BRITAIN WITH SPECIAL REFERENCE TO BRISTOL
}

\author{
by
}

\section{P.S. BROWN*}

A SURVEY of the providers of medical treatment in mid-nineteenth-century Bristol, based mainly on data from the 1851 census, showed the herbalists and their allies as a small but definable group. ${ }^{1}$ They tended to live in the poorest parts of the city and in this, as well as in many other characteristics, they were situated at the opposite social pole to the opulent physicians. Their patients must have been drawn largely from the unknown poor and for this reason, if for no other, they should be worth studying: medicine has so commonly been seen from the perspective of the orthodox practitioners. The contrast was sharpened in the first half of the nineteenth century by the arrival from America of new ideas about herbal medicine which forced both the medical profession and the new herbalists to confront each other in extreme, and consequently revealing, postures. Against this background, the herbalists working during the two middle decades of the century in Bristol have been investigated.

\section{ORIGINS, TRADITIONS AND NEW DEPARTURE}

Much of the herbalists' tradition sprang from the same roots as the therapeutics of the regular medical practitioners, who still relied heavily on the vegetable materia medica. Some clues about the plants that may have been used by the traditional herbalists in Bristol come from a small British herbal published there in $1838 .{ }^{2}$ It claimed to be a practical treatise on the use of the common British herbs and was by William Kemsey, described as a surgeon practising in Bristol. ${ }^{3}$ Even though Kemsey does not appear to have had any formal qualifications, he was clearly anxious to identify himself with established medicine: he dedicated the book to a physician at the Infirmary, and the subscribers included two Bristol "surgeons". Kemsey wrote of the great improvements in materia medica recently made by the Apothecaries' Society and the College of Physicians; and sixty-four of the 169 herbs mentioned can be

* P. S. Brown, B.A., B.M., M.R.C.P., Department of Pharmacology, University of Bristol, Medical School, University Walk, Bristol BS8 1TD.

'P. S. Brown, 'The providers of medical treatment in mid-nineteenth-century Bristol', Med Hist., 1980, 24: 297-314.

2 W. Kemsey, The British herbal, Bristol, [the author], 1838.

${ }^{3}$ Kemsey appeared irregularly in Mathews' Bristol Directory between 1807 and 1833, practising finally in Temple Street.

"One of the "surgeons" was apparently the type of general practitioner usually described by this term, but the other would hardly have liked the description as he was a well-established physician. 


\section{P. S. Brown}

identified in the official pharmacopoeias. ${ }^{3}$ Even so, this leaves the large majority which were not "official".

The unofficial herbs on Kemsey's list were probably in general use by herbalists, more than eighty per cent of the 169 being mentioned in Gray's or Rennie's supplements to the pharmacopoeias. ${ }^{6}$ Rennie occasionally comments on a herb as "much used by herbalists" (e.g., St. John's wort) or, more disparagingly, as "employed by herbalists and old women" (e.g. fleur-de-lis). That Kemsey is giving at least a partial account of the herbalists' materia medica appears even more likely when his volume is compared with a nineteenth-century version of Culpeper's English physician and British herbal. ${ }^{7}$ With two exceptions, all the non-official herbs mentioned by Kemsey are mentioned in this edition, often by identically spelt trivial names and sometimes showing the same non-alphabetical vagaries of sequence. Kemsey, though omitting reference to the influence of heavenly bodies, had evidently drawn freely on earlier sources, suggesting that these herbs, as well as being in use by herbalists, were perhaps used even by unqualified surgeons.

Apparently Kemsey had discarded, or at least did not admit to, astrological considerations. This would not have been the case for some of Bristol's mid-century herbalists, many of whom probably held also to magical traditions which had long been discarded by the regular practitioners. The background to magical healing in earlier centuries has been detailed by Keith Thomas, and the continuing pattern of folkmedicine traced by Black. By mid-nineteenth century, illustrations of magical practices were commonly drawn from the countryside. A description of rural practice in the Lancet of 1846, claimed that "We have white-witches, and black-witches, charmers of burns and scalds, casters of nativities, and foretellers of the fate of parturient women".9 Reports of magical practices in Bristol newspapers were also commonly from rural areas. A child dying of burns in the Forest of Dean had been carried two miles to a "wise-woman" and two miles back, the parents believing that the charmer could do more good than any surgeon. ${ }^{10} \mathrm{~A}$ year previously, another child had died of burns in the same area and the inquest was told of a chain of referral involving three women who supplied various treatments, the final one pronouncing a "mysterious charm" in which the parents had implicit faith. ${ }^{11}$ Nearer Bristol, a sawyer dying of erysipelas, although under orthodox medical care, had persuaded two friends to carry him over a bridge so that, by crossing water, he would be freed from the power of the witches he believed to be the cause of the illness. ${ }^{12}$

\footnotetext{
${ }^{3}$ This is not the full number of herbs mentioned in the book as the copy available for study had one-sixth of the relevant pages missing.

- James Rennie, $A$ new supplement to the pharmacopoeias, 4th ed., London, Baldwin, Cradock \& Joy, 1837; S. F. Gray, A supplement to the pharmacopoeias, London, T. \& G. Underwood, 1818.

'Culpeper's English physician and British herbal, to which is added The family physician, edited by E. Dickenson, London, J. Bumpus, 1814.

- Keith Thomas, Religion and the decline of magic, London, Weidenfield \& Nicolson, 1971; William George Black, Folk-medicine; a chapter in the history of culture, London, Folklore Society, 1883, pp. 191-203.

- Lancet, 1846, i: 485.

${ }^{10}$ Bristol Times and Bath Advocate, 25 January 1851.

"Bristol Mirror, 5 January 1850.

12 Ibid., 16 July 1853.
} 
Magical beliefs were not, however, confined to the countryside. Early in the century, Southey had written that cunning men and women could be found "near" every town, and newspaper reports mention them in cities. ${ }^{13} \mathrm{~A}$ laundress from Gloucester, for instance, consulted a wise woman in Tewkesbury and later used a similar person in her own city: ${ }^{14}$ and a woman from rural Somerset travelled into Bristol to consult a cunning man because she believed that her pigs were bewitched. ${ }^{15}$

Some Bristol herbalists were certainly associated with astrology, and there is some evidence of magical practices. William Derrick appeared in the local directories in the late 1840 s as "medical botanist, student in physic and astrology", and Thomas Randall, who is recorded as a herbalist in the 1851 census, appears as an astrologer in the directories and poll book. ${ }^{16}$ Israel Firman was a colourful character who might be expected to reach well back into tradition as he was recorded in the 1851 census as a herbalist aged 102. This tallies with the age he gave when appearing as a witness in the Newport chartists' trials. He claimed to have been apprenticed to a herbalist in Philadelphia and to have practised in Britain after being pressed into the British navy when in Antigua. Witnesses referred to him as a quack doctor, and one deposition was that "they call him a Quack Doctor and Old Conjuror and a Fortune Teller". ${ }^{17}$ After the trial he moved to Bristol where an advertisement suggests that he carried on a similar practice. ${ }^{18}$ Astrology also appeared in Bristol in a non-medical context and, when it was used purely to obtain money by fortune-telling, the magistrate appeared willing to suppress it. ${ }^{19}$

Many of the herbalists clearly relied on a long-established tradition, but early in the century a movement emerged in America which claimed to be based on an entirely new system for using medicinal plants and which, when it reached Britain, found enthusiastic support in some quarters. It was violently antagonistic to the medical establishment and appealed directly to the poorer classes who had little chance of commanding the price of orthodox medical treatment. Samuel Thomson, its originator, published a record of his life and medical discoveries, subtitled "an account of his system of practice, and the manner of curing diseases with vegetable medicine, upon a plan entirely new" ${ }^{20}$ His simple concept was that loss of internal heat caused disease and that replenishing this heat was the only way to regain health. He argued that the constitutions of all mankind were essentially the same, and "that all disease proceeded from one general cause and might be cured by one general

${ }^{13}$ Robert Southey, Letters from England, edited by J. Simmons, London, Cresset Press, 1951, p. 295.

14 Bristol Mirror, 21 May 1859.

is Bristol Mercury, 10 July 1858.

${ }^{16}$ Description as a student of physic and astrology was common in London in the seventeenth century, see H. G. Dick, 'Students of physic and astrology. A survey of astrological medicine in the age of science', $J$. Hist. Med., 1946, 1: 300-315, 419-433.

${ }^{17}$ Monmouthshire Merlin, 7 December 1839; Depositions relating to the chartists' trials. Newport. 1839-40, Newport Reference Library accession no. 42747, vol. 3, p. 99: I am grateful to Mrs. B. Strong, reference librarian, for locating this material.

18 Lancet, 1840, 35: 287.

19 Bristol Mercury, 10 November 1855; Felix Farley's Bristol Journal, 26 July 1845.

${ }^{20}$ Samuel Thomson, $A$ narrative of the life and medical discoveries of Samuel Thomson, containing an account of his system of practice, and the manner of curing diseases with vegetable medicine, upon a plan entirely new, 2nd ed. Boston, [the author], 1825. 
remedy". ${ }^{21}$ He therefore commonly followed the same course of treatment which entailed an emetic dose of Lobelia inflata, stimulants such as cayenne pepper, and a steam vapour bath. The full course was heroic treatment, as recipients could testify, ${ }^{22}$ but the system gained a great following and gave rise to a considerable commercial organization in America. ${ }^{23}$

\section{THE THOMSONIAN SYSTEM IN ENGLAND}

Albert Isaiah Coffin brought the Thomsonian system from America, and his name, which delighted his medical opponents, was often applied to its practice. He organized "botanic societies" at Huddersfield, Halifax, Brighouse, Manchester, and other places, and a Friendly Botanic Society of Great Britain, membership of which was obtained by purchasing a copy of Coffin's Botanic guide to health. ${ }^{24} \mathrm{He}$ recruited followers by visiting a town and lecturing, while encouraging the formation of a local society and appointing agents for the sale of his medicines and of his book, which was an instructional manual for their use. He lectured in Bristol in 1851 with the title of "Dr. Coffin's popular lectures on medical botany and the natural pathology of disease". ${ }^{25}$

Coffin was not the only one to popularize the system. George Stevens, of Bristol, in his People's guide to the new botanic treatment of disease, claimed that in 1840 , he and his brother, John Stevens, had been "two out of the three who first introduced the American Botanic Practice of Medicine". ${ }^{26} \mathrm{John}$ Stevens made the same claim in his book, entitled Medical reform. When he wrote this his practice was in Nottingham and Derby, and apparently extended into the Potteries where he probably followed the same system as Coffin, as he quotes testimonials "published by order of the Botanic Societies of Tunstall, Hanley and Longton". ${ }^{27}$ Later he had an address in Birmingham. Another major influence was John Skelton, who practised in Leeds probably from the late 1840s. He too wrote, lectured, and appointed agents who sold his preparations. ${ }^{28}$ And there were others, such as William Fox and Joseph Nadin of Sheffield who jointly wrote a small volume on the botanic system of medicine. Rivalry apparently existed among the leaders in botanic medicine, as Fox and Nadin, who

${ }^{21}$ Ibid., p. 43.

${ }^{22}$ F. G. Halstead, 'A first-hand account of a treatment by Thomsonian medicine in the 1830s', Bull. Hist. Med., 1941, 10: 680-687.

${ }^{23}$ A. Berman, 'The Thomsonian movement and its relation to American pharmacy and medicine', ibid., 1951, 25: 519-538.

${ }^{24} \mathrm{~A}$. I. Coffin, $A$ botanic guide to health, and the natural pathology of disease, 5 th ed., Manchester, [the author], 1846.

${ }^{25}$ Bristol Mercury, 25 October 1951. Coffin lectured at the Broadmead Rooms, charging from $2 d$. to $6 d$. for admission. Coffinism is discussed extensively in J. V. Pickstone, 'Medical botany. (Self-help medicine in Victorian England)', Mem. Manchester Lit. Philos. Soc., 1976-77, 119: 85-95.

${ }^{26}$ George Stevens, The people's guide to the new botanic treatment of disease: a handbook of domestic medicine, London, Kempster, 1881, end-page advertisements.

${ }^{27}$ John Stevens, Medical reform; or physiology and botanic practice for the people, 3rd ed., London, Whittaker, 1848, pp. ix-xi, end-page advertisements.

${ }^{28} \mathrm{John}$ Skelton, The epitome of the botanic practice of medicine, or, book of health for the millions, Leeds, Samuel Moxon, 1855, p. 105. John Boot, father of Jesse Boot, was an agent of Skelton, see Stanley Chapman, Jesse Boot of Boots the chemists: a study in business history, London, Hodder \& Stoughton, 1974, pp. 34-35. 
were directly influenced by Coffin, remarked that "Whatever sect or party may have risen up in the botanic cause, whether Thomsonians, Stevenites, Beechites, Skeltonites, all owe their origin in this country to Dr. Coffin". ${ }^{29}$

A basic attitude of the Thomsonian practitioners was intense antagonism towards the medical establishment. The therapeutic procedures and medicines of the regular practitioners were seen as commonly lethal and, in Coffin's words, "thousands perish under their hands who would otherwise have survived", and, he continued, "Mercury, opium, alcohol, and the use of the lancet, are of themselves sufficient to account for the speedy depopulation of a world". ${ }^{30}$ With equal vigour the professional attitudes and social pretensions of the doctors were attacked. A passage written by John Stevens conveys much of the flavour of their anti-medical feelings. He pointed out that a tax-gatherer extracts payment only at a specified rate, but

the licensed to kill enters the house of sickness, and, at the bedside, takes in charge, with the authority of law, his exclusive right over the prostrate victim, whose blood he draws, whose frame he tortures, whose bowels he secretly poisons, and whose disease he cures, or, at his will, prolongs; but kill or cure, his charge is made, in amount wholly at his own discretion; and should his depletion be the cause of death, nothing can be said against it, it was done according to rule .... ${ }^{31}$

If the botanic practitioners were to reject wholly the principles and practice of the orthodox doctors it was logically necessary that their own therapy should be novel. Thomson had been at pains to list the occasions when "the mother of invention held forth her hand" to him. He had discovered the emetic effect of lobelia by tasting it himself, and its beneficial action by giving it to a man working with him on the farm, apparently for amusement. Thomson had invented "steaming" to ease the obstructed respiration of his two-year-old daughter and proved its more general value when it relieved his wife who appeared to be dying after childbirth. Thomson's explanations of his "discoveries" sometimes sound contrived, but he clearly appreciated the need for novelty. ${ }^{32}$

Coffin acknowledged his debt to Thomson but also claimed to have derived useful knowledge directly from the American Indians. ${ }^{33}$ This implies some dilution of the newness of the system by calling on established tradition but, as late as 1881, George Stevens was still writing of "the new botanic treatment of disease" as "a system reared upon newly-acknowledged principles of Nature". ${ }^{34}$ John Stevens appears to have taken the new system of treatment directly from Thomson's writings and the course as he describes it commenced with an enema, followed by a very hot steam bath while the patient drank a warm, sweetened infusion of bayberry (Myrica cerifera) and

\footnotetext{
29 William Fox and Joseph Nadin, The working man's family botanic guide; or every man his own doctor, Sheffield, Dawsons, 1852, p. 13. Mention should also be made of Charles Whitlaw, though not as a member of this movement. He came from America and in the 1820 s used steam vapour baths to treat scrofula and fevers, and introduced his tincture of lobelia, see C. Whitlaw, A treatise on the causes and effects of inflammation, fever, cancer, scrofula, and nervous affections, London, [the author], 1831, pp. 173-177. Samuel Thomson complained that Whitlaw had obtained information about his system of treatment, see Thomson, op. cit., note 20 above, p. 166.

${ }^{30}$ Coffin, op. cit., note 24 above, pp. xi, 70.

31 John Stevens, op. cit., note 27 above, p. xiii.

32 Thomson, op. cit., note 20 above, pp. 15, 20-21, 27, 29-30, 33.

${ }^{33}$ Coffin, op. cit., note 24 above, introductory address.

${ }^{34}$ George Stevens, op. cit., note 26 above, introductory page.
} 


\section{P. S. Brown}

cayenne pepper. The vapour bath was followed by splashing with cold water, brisk towelling, and removal to a warm bed. The patient was then given a powerful emetic based on lobelia and cayenne pepper and, after copious vomiting, was in the full course subjected to a second vapour bath. ${ }^{35}$ The separate elements of the treatment were not new, so it could be argued that Thomson discovered very little. ${ }^{36}$ But the whole course was certainly a novel pattern of assault on the sick.

Perhaps the most important attribute of the "botanic system of practice" was that it was medicine for the people. This idea was paraded in the titles of many of the books written, in Coffin's words, to "enable the millions in this country to prescribe for themselves". ${ }^{37}$ John Stevens subtitled his book the botanic practice for the people, ${ }^{38}$ while George Stevens described his as The people's guide. ${ }^{39}$ Skelton's was: The book of health for the million, ${ }^{40}$ and Fox and Nadin's explicit title was The working man's family botanic guide; or every man his own doctor. ${ }^{41}$

The founding of Friendly Botanic Societies was seen by John Stevens as a way in which "the people may mutually assist each other in the study of Medical Botany, and establish and propagate a general knowledge of these principles, so glorious in eradicating disease from society, and relieving it of much of that poverty and deplorable suffering which arise from wrong practice". ${ }^{42}$ Skelton claimed that "almost every town of any note" had its evening school for mutual instruction and that the disciples of the botanic system "belong to the working order, and their influence lies in their numbers, poverty, and faith". Skelton wrote to help "the poorest of his fellow countrymen to help themselves" and "to rescue the poor and needy from medical bondage". ${ }^{43}$ Coffin quoted grateful testimonials from the labouring and industrial classes of Bradford and Keighley and, in return, was reported as saying at Sheffield that he believed the working classes were "the only classes who deserved to have any good done to them".4

Much of the evidence about the medical botanists, other than the few leaders, comes from an unfortunately selective source - accounts of inquests held when patients died or when Coffinites were charged with manslaughter. Rarely were they described as full-time practitioners: more commonly their normal occupations were quoted and sometimes they were said to be agents of Dr. Coffin. The medical press delighted in parading their humble trades, and no doubt there was some bias in selection. The occupations of the medical botanists ranged from blacksmith and bookseller to factory labourer and cotton spinner. ${ }^{45}$ Limited information about the occupations

$3 s$ John Stevens, op. cit., note 27 above, pp. 302-309.

$36 \mathrm{~J}$. M. Ball, 'Samuel Thomson (1769-1843) and his patented system of medicine', Ann. med. Hist., 1925, 7: 144-153.

${ }^{37}$ Coffin, op. cit., note 24 above, pp. v-vi.

38 John Stevens, op. cit., note 27 above.

${ }^{39}$ George Stevens, op. cit., note 26 above.

${ }^{40}$ Skelton, op. cit., note 28 above.

${ }^{41}$ Fox and Nadin, op. cit., note 29 above.

42 John Stevens, op. cit., note 27 above, p. xi.

${ }^{43}$ Skelton, op. cit., note 28 above, pp. iv-v; John Skelton, A plea for the botanic practice of medicine, London, J. Watson, 1853, p. 199.

4 Coffin, op. cit., note 24 above, pp. 322-323, 325; Sheffield Times, 21 August 1847.

is Occupations named in reports from coroners' or other courts were boot or shoemaker, wife of a 
of their patients is available from the same source. Of sixteen patients dying, six were children, two were female servants, one was a labourer, and one a labourer's wife; there was a bookseller's wife, a joiner, an ostler, and a pilot; and even the "wife of a retired gentleman" and a "widow lady of fortune".

John Stevens used Medical reform as the title of his book and, while applauding recent political reforms, he appealed "to reformers, the lovers of truth, the friends of suffering humanity" on the urgent necessity for medical reform. ${ }^{46}$ "Medical reform" was also the title used in connexion with a meeting at Exeter Hall addressed by Coffin, ${ }^{47}$ and for George Stevens's lectures in Bristol. ${ }^{48}$ This use of the phrase implied something different from its interpretation by the medical profession, who were surprised and indignant when twenty-five individual medical botanists or groups petitioned parliament for special consideration when one of the abortive medical registration bills was under discussion. To the editor of the Medical Times and Gazette this was equivalent to murderers and poisoners petitioning for parliamentary protection when a new criminal law was under consideration. ${ }^{49} \mathrm{~A}$ medical commentator, describing a meeting of "Herbalists or Coffinites to oppose Dr. Brady's Bill", reported that "there was an amount of intelligence among these artisans that quite astonished me; they quoted Bacon and Harvey; and some very gentlemanlike men, in the guise of banker's clerks, grocers, etc., had evidently studied well the medical journals, and moved resolutions in capital speeches ...".,.30

Though the evidence is less than ideal, it seems that "botanic medicine" did reach the poor, the labourers, and the female servants. The practitioners, armed with Coffin's Botanic guide to health or equivalent volume, seem usually to have been a little higher in the social scale and some appear to have been fluent advocates of their cause. And there is some evidence of association between the medical botanists and various non-conformist sects. Coffin wrote that he felt under great obligation to many members of the Society of Friends, and he had been presented with a pair of spectacles by the quakers of Leeds. ${ }^{31} \mathrm{He}$ recommended complete avoidance of alcohol, and was presented with addresses of thanks, and sometimes more material gifts, in temperance halls and non-conformist halls and chapels..$^{52}$ John Boot, when he came under the influence of John Skelton, was an active Wesleyan and local preacher: ${ }^{53}$ and most interesting is a report of association with Primitive Methodism which must have some basis. A writer in the Carlisle Patriot claimed that the chief feature of Coffinism "is the almost total monopoly of it by religious Dissenters of the most zealous castes....

\footnotetext{
journeyman baker, bookseller and newsman, greengrocer, ostler and porter, bricklayer, shopkeeper, blacksmith, factory labourer, grocer and potato salesman, and cotton spinner. Other occupations mentioned by the medical press in a general context, but not related to specific individuals, were woolcomber, stonemason, engineer, and victualler.

46 John Stevens, op. cit., note 27 above, p. xii.

${ }^{47}$ Med. Times Gaz., 1851, 3: 213-214.

48 Bristol Times and Bath Advocate, 31 March 1849.

${ }^{49}$ Med. Times Gaz., 1854, 8: 491-492.

so Medical Circular and General Medical Advertiser, 1854, 4: 263-264.

${ }^{31}$ Coffin, op. cit., note 24 above, preface; Sheffield Times, 21 August 1847.

32 Coffin, op. cit., note 24 above, appendix, pp. 322-325.

${ }^{33}$ Chapman, op. cit., note 28 above, pp. 32-35.
} 


\section{P. S. Brown}

Lobelia inflata, is collected in America, and sent to this country by the sect called Shakers; and the rash and often fatal exhibition of it is, it would appear, chiefly in the hands of the very numerous and untiring body known as Ranters, the Primitive Methodists of our own country."'s4

\section{REACTIONS TO THE THOMSONIAN SYSTEM}

The medical profession reacted vigorously to the Coffinites and their allies. The ideas implicit in the new botanic system were recognized as comprehensively antagonistic to the established position and pretentions of the regular practitioners. The suggestion that ill-educated persons of low social status might successfully practise and prescribe with little more instruction than that contained in Coffin's manual and perhaps a few lectures, was a challenge to the medical practitioners' proprietary rights and achieved power, as well as to their status as members of a learned profession or, at least, one requiring prolonged study. The number of medical botanists seemed large, editorial comment in the Medical Times suggesting that they represented a major proportion of an estimated 6,000 irregular practitioners. ${ }^{5 s}$ And their threat came at a time when the profession was very alert to the detection of "quackery" and was attempting to formalize its organization despite internal power struggles.

The Lancet and other journals provide ample evidence about medical attitudes towards "that most ignorant of all species of quackery, appropriately termed "Coffinism'." 36 Reports of inquests and assizes provided both context and ammunition for the medical attack. It was claimed that Coffinites "furnish, on an average, two or three cases of trial for murder and manslaughter for every assize," 37 and editorial comment in the Medical Times declared that the "newspapers in different parts of the country have already recorded so many instances of death following the use of the deleterious drug recommended by Coffin, and exhibited most rashly and ignorantly by uneducated imposters, that it is quite time that Government should interfere." 98

Regular practitioners could influence inquests, being called on to establish the cause of death, and verdicts of manslaughter by Coffinites were common in coroners' courts: ${ }^{59}$ but they were less common when cases reached the assizes. ${ }^{60}$ Often the medical profession had to be content with Coffinites being prosecuted for acting as

\footnotetext{
54 Carlisle Patriot, 11 August 1849, quoted in Pharm. J., 1950, 9: 97-99. The supply of lobelia by the Shaking Quakers of New Lebanon is confirmed by Jonathan Pereira. The elements of materia medica, London, Longman, Orme, Brown, Green \& Longman, 1840, part 2, p. 946.

ss Med. Times Gaz., 1854, 8: 491-492.

s6 Lancet, 1850 , i: 766 .

s7 Ibid., 1850, ii: 279-280.

s8 Med. Times Gaz., 1850, 22: 611 .

${ }^{99}$ Lancet, 1850, i: 766; 1853, i: 215; 1853, ii: 473-474; Prov. med. surg. J., 1849, 335; 1850, 355-360. Med. Times Gaz., 1853, 6: 231; 1853, 7: 532-533; Pharm. J., 1852, 11: 87-88.

${ }^{60}$ Lancet, 1849, ii: 275-276; 1850, ii: 250; 1851, ii: 209; Br. med. J., 1860, 789-794; Med. Times Gaz., 1850, 21: 259-260; 1853, 6: 270-272; 1853, 7: 532-533; 1856, 13: 94; 1859, 18: 305; Pharm. J., 1850, 9: 99-101; 1852, 11: 141; The Times, 6 August 1849, 25 March 1850, 5 August 1850, 25 August 1851, 23 March 1858, 16 March 1859.
} 
apothecaries without the necessary licence. ${ }^{61}$ The Pharmaceutical Journal commented that at some inquests "the medical witnesses have apparently endeavoured to prove too much", and when a Coffinite named John Wood was charged with manslaughter the defence alleged that "the doctors ... had been concerned in getting up the case". ${ }^{62}$ Prejudice perhaps shows in the varying descriptions of John Wood in reports of the trial. The Times called him "a young man of excellent character, and given to reading", while the Lancet recorded simply that he "reads and writes well". ${ }^{63}$ In another trial, counsel for the prisoner contended that the case "had evidently been got up by the medical men residing in the neighbourhood, in order to put a stop to what they no doubt considered the improper interference of the prisoner with the profits of their profession". 64 In Bedford, a herbalist was charged with killing a child by prescribing lobelia, the case getting as far as the assizes despite the fact that the herbalist had not seen the child for three weeks before its death and the patient had improved considerably while taking his medicine. ${ }^{65}$

Cases against the botanic practitioners were based mainly on the toxicity of the lobelia they used. Post-mortem material was often analysed by Dr. Henry Letheby of the London Hospital who claimed in 1853 that there had been thirteen poisonings by lobelia in the previous three or four years and, on another occasion, that this herb had caused a total of twenty-two deaths in Britain. ${ }^{66}$ But Coffin claimed that lobelia was innocuous. He entirely disagreed with Hooper's dictionary that the drug was a narcotic poison, directing that "care should be taken to give enough, so as to cause it to operate; more than this will do no harm ... never mind Hooper, but give enough". ${ }^{67}$ John Stevens expressed similar views, never having seen toxicity "from its most copious use", while Fox and Nadin claimed that lobelia was "as harmless as milk".68 One important cause for this conflict of views was probably the influence of prejudice in apportioning the blame for the patient's deterioration to the disease itself or to the lobelia used in treatment. In addition, there was probably variation in the potency of different batches of the herb, and, in any case, the toxic effects of a large dose would usually have been self-limiting because of its emetic effect. ${ }^{69}$

The prejudice of the doctors was recognized in several quarters. The judge in a trial of a botanic practitioner for manslaughter commented that "If people were to be tried

${ }^{61}$ Lancet, 1847, i: $419-421 ; 1854$, i: 169 . Coffin claimed legality because he had been in practice before 1815 , and at one time he was in partnership with Thomas Harle who seems to have been regularly qualified as a surgeon, see Prov. med. surg. J., 1850, 355-360. Lancet, 1847, ii: 288-289; Pharm. J., 1847, 6: 437.

62 Ibid., 1850, 9: 101; 1851, 10: 383.

${ }^{63}$ The Times, 6 August 1849; Lancet, 1849, ii: 275-276.

at The Times, 25 August 1851 .

${ }^{65}$ Ibid., 16 March 1859; Med. Times Gaz., 1859, 18: 305.

6 Ibid., 1853, 7: 568; Lancet, 1853, ii: 473-474; Letheby also wrote an article on Coffinism for the lay press in a series on 'The mischievous effects of Quack Medicines', Family Friend, 1856, 2: 91-95. Interest in lobelia also produced publications on its detection, in Lond. med. Gaz., 1851, 8: 160 and Br. med. J., 1860, 799-800; and on its effects on animals, in Prov. med. surg. J., 1858, 493-495.

${ }^{67}$ Coffin, op. cit., note 24 above, pp. 98-99.

John Stevens, op. cit., note 27 above, p. 112; Fox and Nadin, op. cit., note 29 above, p. 47.

${ }^{69}$ Both Elliotson and Whitlaw mention variation in the potency of lobelia and its preparations, see Lancet, 1837, ii: 144,299 . 
on the judgement of old practitioners for acting contrary to received notions there would never be any improvement in medicine". ${ }^{70}$ A writer in the Saturday Review claimed that "neglect of the more novel systems of hygiene by the ordinary run of medical men" drove patients to the irregular practitioners, and even a reviewer from the medical ranks suggested that useful information might be obtained from the "empirics" by "carefully watching the progress of all their cases". ${ }^{11}$ And, at all events, large sections of the population had little interest in the political struggles of the medical profession: a commentator in a conservative Bristol newspaper did not believe the country cared a straw about them. ${ }^{72}$

But sections of the working classes responded enthusiastically to ideas about medical reform as preached by the medical botanists. A local newspaper described the presentation of a testimonial to Coffin in Sheffield as a tumultuous affair in which he was "greeted with uproarious and protracted applause". ${ }^{73}$ Loud clapping, "which continued for some time before it could be suppressed by the officers of the court" was also heard when John Wood was found not guilty of manslaughter. ${ }^{74}$ And the release of Ellis Flitcroft, a Coffinite imprisoned for one month for acting as an apothecary, was described as the occasion for a triumphant procession "drawn by four horses, and accompanied by Dr. Coffin and others, the temperance band playing through the streets". They were preceded by several banners and a flag inscribed "Release of the persecuted Flitcroft". ${ }^{\text {. }}$

\section{BRISTOL HERBALISTS}

The situation in Bristol has been examined against the general background so far discussed. Thirty-one herbalists of various types have been identified as practising in Bristol between 1841 and 1861 and are listed in an appendix. This group probably includes most of the well-established practitioners but is likely to be less representative of the poorer herbalists who may not have described themselves in these terms and whose type of practice may not, in any case, have been easy to define. There must have been only subtle gradations between treating one's family with simple herbal medicines, extending similar help to neighbours, and acquiring some local reputation as a herbalist.

If herbalism frequently followed established tradition it seems likely that the knowledge and practice would be passed down through generations of the same family. This seems to have occurred with the Purnells, first represented by an unqualified "practitioner of surgery" earlier in the century, and probably with the practice of the Randall family. One of the latter called himself an astrologer but later the main interest of the Randalls shifted to medical galvanism, and in the 1861 census Charles Randall, who eventually dropped the designation of herbalist, was described as an astronomer, perhaps in error or perhaps purposely to repudiate earlier associa-

\footnotetext{
70 The Times, 25 March 1850.

"Saturday Review, 1858, 6: 30; Br. for. med. chir. Rev., 1850, 5: 285-310.

12 Felix Farley's Bristol Journal, 10 May 1845.

${ }^{33}$ Sheffield Times, 21 August 1847.

74 Lancet, 1849, ii: 275-276.

75 Halifax Guardian, 8 May 1847, quoted in Lancet, 1847, i: 526.
} 
tion with astrology. William Derrick, the "student in physic and astrology" clearly had traditional roots, but it is difficult to know who else falls into this category. Perhaps it would include John Hamlyn, who was listed as a herbalist after describing himself for many years as a "successful curer of the cholera", and possibly Atkinson and Burton who were already in their fifties in 1841 .

In contrast to the traditional herbalists were the followers of Samuel Thomson. George Stevens opened his "American Botanical Dispensary" in Bristol in 1847, at the age of about twenty-seven. He called himself a medical botanist but at first was described as Dr. Stevens in newspapers and directories. He lectured in Bristol and Newport, ${ }^{76}$ and was probably the "Dr. Stephens" whose course of medical lectures in Bath was mentioned by a miner turned medical botanist at Paulton on Mendip. ${ }^{71}$ Lecturing was clearly a normal activity for Thomsonian practitioners, and in 1881 Stevens still described himself as a lecturer. He achieved some prosperity from his herbal practice or from the additional trade of gold beater which he carried on from 1855. By 1861 , he and an extended family group had a residence away from the shop, with a household size of fifteen and two resident servants. His herbalist business continued for more than a hundred years, the name of George Stevens still being used up to $1950 .{ }^{78}$

Others in the Thomsonian movement included two agents of Drs. Coffin and Harle. Little is known of one, but the other was Samuel Thatcher who ran a temperance coffee house and so was well suited to be an agent of Coffin. ${ }^{79}$ Bristol was also colonized by other American "botanical doctors" who, even if not directly disciples of Thomson, probably owed many ideas to him. In 1855, Startup and Brown announced under the heading of "All Diseases Cured by means of Herbs, Roots, Bark and Flowers" that they had taken premises in High Street and each evening would lecture on medical botany. Their advertisement suggests a permanent settlement, but the directories do not record a long or successful stay. Their highly commercial advertisement was in striking contrast with another in the same newspaper by the Nottingham Medical Botanic Society offering a botanic remedy for indigestion free of charge, purely in the cause of "Medical Reform".80 Also presumably American was Thomas Airey, who lectured and practised as a botanical doctor in Castle Street in 1859 . He described himself as Dr. Airey, M.B., M.R.C.S. and M.R.C.P., and consequently was

\footnotetext{
${ }^{76}$ Bristol Times, 31 March 1849; Stevens lectured at the Broadmead Rooms: his title was 'Medical reform', and the cost of admission $2 d$. or 3d.; George Stevens, op. cit., note 26 above, p. 67.

"An inquest on a patient of Joseph Verrier, the ex-miner, was reported in Bristol Mirror, 16, 23, and 30 April 1853. Verrier had attended weekly lectures for a year in 1849-50, and said that thirty or forty others also attended. As well as lecturing, Stevens appears to have experimented with a branch establishment in Union Passage, Bath, from 1852 to 1856, see Bath directories. In 1850, William Emmett at the same address is listed as an agent for Dr. Stevens's medicines.

"Kelly's Bristol Directory, Bristol, 1950. Fox's business in Sheffield also continued into the twentieth century, when lobelia, emetics, and vapour baths were still recommended in William Fox, The workingman's model family botanic guide, 24th ed., enlarged by A. R. Fox, F.L.S., M.P.S., Sheffield, William Fox, 1932. Similar treatments are suggested in George Slack, Slack's herbal. A treatise of the pathology of disease, 13th ed., London, Potter \& Clarke, 1925.

${ }^{79}$ Coffin expected his followers to conform to his views on alcohol and, at Sheffield, told them that "you botanical fellows must ... give over smoking and drinking". See Sheffield Times, 21 August 1847.

${ }^{80}$ Bristol Mercury, 10 and 17 March 1855; issues for January and February 1855 for Nottingham society advertisement.
} 


\section{P. S. Brown}

successfully prosecuted under the Medical Registration Act. He claimed that the memberships were of the Reformed Colleges of Surgery and Medicine of New York, and presumably M.B. stood for medical botanist. ${ }^{\mathbf{B 1}}$ The rank-and-file practitioners of the Thomsonian school were probably represented, together with humbler herbalists of the traditional type, among the twelve individuals identified only from the enumerators' books. Most lived under poor conditions, a third being found in the very poor out-parish of St. Philip and Jacob. Three lived in lodging-houses, while eight were heads of small households, half of these sharing a house with other households. None had any resident servants.

Not identified even in the census returns was a "labouring man" named Baker, noticed because of the inquest on one of his patients. He was variously described as a herb doctor and as "a man that goes about with herbs and attends people with diseased legs". The patient, after her twelfth successful confinement attended by a regular practitioner, had developed pain in one leg. Baker had undertaken to supply a medicine for this: she was unaffected by the first dose but on taking the second "she immediately fell back in bed" and soon died. The story suggests a pulmonary embolism, but no cause of death was identified and suspicion fell on Baker's medicine. Fortunately for him, William Herapath, the celebrated forensic chemist, could find no poison in the medicine. ${ }^{82}$

Data from similar surveys of other towns would be needed to decide whether the total of thirty-one herbalists found over the twenty-one-year period suggests that they were relatively numerous or sparse in Bristol. Large numbers of herbalists in English towns are suggested by the editorial comment in the Medical Times already quoted, but this was a very biased view. So presumably was that of a doctor in Southampton, who instigated action under the Medical Act against a local herbalist because "there were so many herbalists in the town". ${ }^{83}$ But medical writers from Glossop and Leeds, complaining of the great prevalence of quacks in northern manufacturing districts in 1854 , instanced bone-setters and cancer-curers and the treatment of the poor by prescribing druggists, but did not mention herbalists. ${ }^{84}$ This is surprising, as the North seems to have been the home of the botanic societies. In Bristol, none of these societies has been noticed, and this perhaps accords with Coffin's remark that "in manufacturing towns like Sheffield ... the working men are banded together, and communicate information one to another: whereas in commercial towns, there is very little of this mutual communication".

\footnotetext{
${ }^{81}$ Bristol Mirror, 12 and 19 November 1859.

82 Baker claimed that his medicine contained only yarrow, pellitory of the wall, and plantain boiled up with a little lime. William Herapath reported that he himself had drunk $5 \mathrm{oz}$. of the medicine without ill effect, and had seen Baker drink two glassfuls. Dr. William Bird Herapath, son of William Herapath and also a distinguished chemist as well as a prominent member of the medical profession, disagreed with his father and reported that the medicine contained nicotine. Medical bias may have made him more likely to identify a poison in the irregular practitioner's medicine in the event of any test giving an equivocal result, but the jury accepted the evidence of "so experienced an analyst as [the senior] Mr. Herapath". See Bristol Mercury, 6 and 13 November, 1852.
}

${ }^{83}$ Lancet, 1859, i: 623; Med. Times, 1859, 18: 632.

sancet, 1854, i: 402-403, 458.

${ }^{85}$ Coffin, op. cit., note 79 above. 


\section{COMMENT}

Two types of herbalism, the traditional and the Thomsonian, have been discussed as if they were clearly separable, but naturally they overlapped widely. However, there were real differences. Traditional herbalism and orthodox medicine could co-exist without too many problems: they had developed from common roots and presumably had evolved to meet the needs of different social groups. Shortly before the period under discussion, Kemsey's practice in Bristol was acceptable enough for him to be shown as a surgeon in the professional lists, but he was still using Culpeper's herbs if not, overtly, his astrology. Traditional herbalists and regular medical practitioners may even have been used for different purposes by the same patient, as seems to have been the case with the woman whose confinement had been managed by a regular practitioner but who sent for Baker, the herb doctor, to treat the "bad leg" which followed. But no easy co-existence was possible with the Thomsonian herbalists. Their organization was advanced in head-on confrontation with the regular practitioners. They presented a "system" of medicine and publicized it by writing books and lecturing in a manner analogous to that commonly adopted for presenting science to a more middle-class audience. ${ }^{86}$ The Thomsonians' challenge to the medical practitioners was as much social as medical: they involved the working classes and strove "to rescue the poor and needy from medical bondage". ${ }^{87}$ Their aims must therefore be seen as partly political and their activities as parallel to the working-class political movements. ${ }^{88}$

The medical botanists were not the only group to attack established medicine. Shryock comments that a cynical distrust of the medical profession "seemed to grow beyond ordinary bounds during the early Victorian decades".89 Among the poorer classes, John Wesley's criticism of the physicians in his Primitive physic must have been an important and continuing influence, and he was quoted with approval by the medical botanists. ${ }^{90}$ Wesley assembled a collection of recipes for the use of the poor, and these he drew from traditional sources, both of folk-medicine and orthodox practice.91 In this he differed from the Thomsonian botanists and from many others who opposed the regular practitioners. They tended to present a "new" principle of treatment which was often claimed to be of universal application. Some, such as the homoeopaths and mesmerists, had often received an orthodox medical training, while

\footnotetext{
86 The social and cultural importance of institutional lectures on scientific subjects and of those given by itinerant lecturers is discussed by A. Thackray, 'Natural knowledge in cultural context: the Manchester model', Am. hist. Rev., 1974, 79: 672-709; and I. Inkster, 'Culture, institutions and urbanity: the itinerant science lecturer in Sheffield, 1790-1850', in S. Pollard and C. Holmes (editors), Essays in economic and social history of south Yorkshire, Sheffield, South Yorkshire County Council, 1976, pp. 218-232.

${ }^{87}$ Skelton, op. cit., note 28 above, p.v.

It is difficult to identify the political activities of the herbalists, few even appearing in the Bristol poll books. Isaac Firman is hardly representative but, although he was prepared to give evidence against them, he had been associated with the chartists and had attended their meetings, see note 17 above.

${ }^{8}$ R. H. Shryock, The development of modern medicine, Madison, University of Wisconsin Press, 1979 (reprint of 1947 ed.), p. 248.

${ }^{9}$ A. I. Coffin, Botanic guide to health, 31 st ed., London, [the author], 1859, pp. 70-75; John Stevens, op. cit., note 27 above, p. xiv; George Stevens, op. cit., note 26 above, pp. xv-xvi. Wesley's name was sufficiently familiar and potent to be appropriated for "Wesley's Family Pills", advertised half a century after his death, see Bristol Mercury, 30 July 1842.

${ }^{1}$ S. J. Rogal, 'Pills for the poor: John Wesley's Primitive physick', Yale J. Biol. Med'., 1978, 51: 81-90.
} 


\section{P. S. Brown}

many others were as devoid of this training as the majority of the medical botanists. ${ }^{92}$

Defiance of orthodox medicine may have had some bearing on the efficacy of the Thomsonians' therapy. Shapiro suggests that the history of medical treatment is largely the history of the placebo effect: ${ }^{93}$ it is therefore relevant to consider factors which influence it. This is not to say that the botanical medicines lacked pharmacologically active ingredients, and the alarming pharmacological effects and general trauma of a Thomsonian course of treatment may, of themselves, have caused amelioration of symptoms in some conditions. Hench noted in his Nobel lecture that symptomatic remissions could be induced in rheumatoid arthritis not infrequently by almost any surgical operation. ${ }^{94}$ At that time, exaggerated adrenocortical activity was seen as the cause of this phenomenon, but future explanations may widen to involve the endogenous opioids.

Even assuming no useful pharmacological effect, the setting in which the Thomsonians gave their medicines may have made a beneficial effect more likely. Totman, in a stimulating discussion of the efficacy of past therapies, suggests that many were effective because they set up a considerable degree of cognitive dissonance which could be resolved by symptomatic improvement. ${ }^{95}$ Strong personal commitment to a gruelling course of treatment would be helpful in setting the scene and might well have occurred among fervent converts to botanic medicine acting within self-help societies and fired by an eloquent lecturer. Reports of the trial of John Wood note that he carefully explained the proposed course of treatment to obtain approval before proceeding:96 and John Stevens advised full discussion with the patient and his friends before starting a course, because alarming symptoms might occur.97 Such explanations would be particularly effective in setting up cognitive dissonance in a patient who knew that the proposed treatment was fiercely opposed by the medical profession, who declared it dangerous or even lethal.

Confrontation with the medical profession could not continue indefinitely and, while consideration of the lasting influence of the Thomsonian system in Britain is beyond the scope of this discussion, it is worth noting briefly its changing relationship with orthodox medicine. During the second half of the century, circumstances and attitudes which might affect the medical botanists were changing: the doctors had achieved some success with medical registration and the chemists and druggists with the Pharmacy Acts; Coffin, the active and outspoken leader, had died in 1866;98 and

\footnotetext{
92 James Morison, for instance, was a retired merchant who attacked the medical profession and solved all therapeutic problems with a universal pill, see William $\mathrm{H}$. Helfand, 'James Morison and his pills. A study of the nineteenth century pharmaceutical market', Trans. Br. Soc. Hist. Pharm., 1974, 1: $101-135$.

${ }_{93}$ A. K. Shapiro, 'The placebo effect in the history of medical treatment: implications for psychiatry', Am. J. Psychiat., 1959, 116: 298-304.

94 Philip S. Hench, 'The reversibility of certain rheumatic and non-rheumatic conditions by the use of cortisone or of the pituitary adrenocorticotropic hormone', in Nobel lectures: physiology or medicine, 1942-1962, Amsterdam, Elsevier, 1964, pp. 311-341.

9s Richard Totman, Social causes of illness, London, Souvenir Press, 1979, pp. 31-60.

Tancet, 1849, ii: 275-276; The Times, 6 August 1949.

97 John Stevens, op. cit., note 27 above, p. 308.

96 William Fox and Sons, Fox's botanic almanack and business advertiser for 1880, Sheffield, [the authors], 1880, p. 14.
} 
the sale of patent medicines was gaining increasing momentum.99 By 1881 , when George Stevens published his book, some changes were apparent. Although it implied a distrust of the medical profession, the book was mild and polite in tone. It is perhaps relevant that, in the 1871 census, one of George Stevens's sons was recorded as a medical student, and a person of the same name with a Bristol address qualified M.R.C.S. in 1874. In 1885, when Phelps Brown's Complete herbalist was published in England, its introduction stated that he did not intend to "oppose the pride, interest, expectations and conscientious convictions of a learned, honorable, and influential profession". ${ }^{100}$ So it seems that the medical botanists had found a niche for themselves and no longer needed to issue challenges or, more probably, accepted that they were in no position to oppose the power of the organized medical profession. ${ }^{101}$

\section{APPENDIX. BRISTOL HERBALISTS, MEDICAL BOTANISTS AND ALLIES, 1841-1861}

\section{FAMILIES OR PRESUMED FAMILIES}

Purnell family: William, 1833 (aged 27) to 1849, medical botanist, Tower Hill (Castle Precinct), born locally. John, 1819-1821, botanist and druggist; 1835 (aged 34) to 1844, dispenser of medicines from British herbs, (quack doctor, PB 1841), Merchant St. (St. James), born locally. (Father of John, and probably of William, was William Purnell sen., who pre-dated survey as practitioner of surgery (1814-1818) and medical botanist (1822-1831). Also Mary Purnell, medical botanist, 1832 only.)

Randall family: Thomas, 1851 (aged 24) to 1854, astrologer, herbalist, medical galvanist (Sc. and PB 1852), Eugene St. (St. James), born Devon. William, 1855-1856, herbalist, medical galvanist, Eugene St. Charles, 1856 (aged 21) to 1869, herbalist, medical galvanist, (astronomer, C 1861), from 1870 medical galvanist only, Eugene and later Dighton St. (St. James), born Tiverton.

\section{THOMSONIAN PRACTITIONERS}

George Stevens, 1847 (aged 26) onwards, medical botanist, Old Market (St. Pauls), born London, see text.

Agents of Drs. Coffin and Harle: W. Taylor, 1851, Temple St. (see Bristol Mercury, 25 October 1851). Samuel Thatcher, 1850-1853, herbalist, temperance coffee house (Sc), Bedminster.

\section{"AMERICAN HER B DOCTORS" AND OTHER IDENTIFIED IN NEWSPAPERS ONLY}

Startup and Brown, 1855 only (see Bristol Mercury, 10 March 1855), American doctors of Liverpool and Glasgow, "All diseases cured by means of Herbs, Roots, Bark, and Flowers", High St. Thomas Airey, 1859 only (see Bristol Mirror, 12 November and 10 December 1859; Western Daily Press, 7 November and 6 December 1859), botanical doctor, herb doctor (presumed American), Castle St., see text. [-]. Baker, 1852 only (see Bristol Times and Bristol Mercury, 6 and 13 November 1852; Bristol Gazette, 11 November 1852), herb doctor, Moorfields, see text.

\footnotetext{
${ }^{99}$ Chapman, op. cit., note 28 above, pp. 11-30.

$100 \mathrm{O}$. Phelps Brown, The complete herbalist; or, the people their own physicians by the use of natural remedies, London, Frederick W. Hale, 1885, p. 3.

101 M. Jeanne Peterson, The medical profession in mid-Victorian London, Berkeley, Los Angeles, and London, University of California Press, 1978.
} 


\section{P. S. Brown}

OTHERS FOUND IN MULTIPLE SOURCES

John Burton, 1837 (aged 51) to 1841, herb dealer (PB), vendor of medicines (C), George St. (St. Mary Redcliffe), born locally. Charles Atkinson, 1841 (aged 55), herbalist (C and PB), John St. (St. Philips), not locally born. John Hamlin, 1841 (aged 41) to 1842, herbalist, Gravel St. (St. James), born locally, (1833-1840, "successful curer of the cholera"). Thomas Smith, 1857 (aged 45) to 1861, botanical dispensary, botanist, (druggist and botanist, C 1861), Passage St. (St. Philips), later Merchant St. (St. Pauls), born London. (A Thomas Smith, botanical druggist, reappeared at this address in 1870.)

OTHERS FOUND IN DIRECTORIES ONLY

William Derrick, 1845-1848, medical botanist, student in physic and astrology, Hill St. (St. Pauls). John Matthews, 1851-1854, herbalist, Bedminster. William Payne, 1850, herbalist, Lower Arcade. Owen \& Co., 1856, medical botanists.

OTHERS FOUND ONLY IN ENUMERATORS' BOOKS

Twelve individuals including two husband-and-wife pairs. Eight herbalists or herbal practitioners (one also a chemist); four medical botanists (one also labourer at corn store). This group included Israel Firman (various spellings), see text.

\section{SOURCES}

The area of study and methods were as defined in Brown, op. cit., note 1 above. Dates and descriptions, unless otherwise stated, are from Mathews' Bristol Directory, which appeared annually throughout the period. A systematic sample of local newspapers was examined. Ages and places of birth are from census enumerators' books for 1841, 1851, and 1861, seen on microfilm at Avon Central Reference Library, to the staff of which I am grateful for continued help with local source material. Other data from census returns are marked $(C)$, from poll books are marked (PB) and from Scammell's Bristol General Directory, 1853, are marked (Sc).

\section{SUMMARY}

Traditional herbalism and orthodox medicine co-existed in the nineteenth century, having evolved to meet the needs of different social groups. In mid-century Bristol, some herbalists identified with tradition by still calling themselves astrologers, but ideas from America had recently introduced a new style of medical botanists. Their new system, which stemmed from Samuel Thomson and had been brought to Britain by A. I. Coffin, was intensely antagonistic both to the therapeutic ideas and the professional pretensions of the regular practitioners. The medical botanists often prescribed lobelia, cayenne pepper, and steam vapour baths: they claimed that their treatment was novel and of universal application. Botanic medicine was for the people and did reach the poor, aften being practised in local self-help societies. Coffin and other leaders, such as George Stevens of Bristol, lectured and wrote instructional manuals. The medical profession reacted vigorously to what they saw as a "most ignorant quackery", and medical botanists were frequently found guilty of manslaughter at inquests, a verdict usually reversed at the assizes. Ideas derived from Thomson persisted to the end of the century, but the medical botanists had to modify their aggressive attitude towards the well-established medical profession. 